\title{
THE BIOLOGICAL STATION OF THE UNIVERSITY OF MICHIGAN.
}

\author{
By H. A. Gleason, \\ University of Michigan, Ann Arbor.
}

In many respects the Biological Station of the University of Michigan differs radically from other stations of similar purpose in the United States. It is distinctly an out-of-door station, out in the woods, away from the railroad, away from all the distracting influences of urban or summer resort life. But it must not be considered that the place is entirely away from civilization. Mail comes out every day, there is a physician, a telephone, and an up-to-date mess-tent. The station embodies all the desirabilities of camp life and avoids all its discomforts.

The University of Michigan owns a tract of 1,666 acres of land adjoining the shore of Douglas Lake, in northern Michigan, and stretching across to Burt Lake, one of the largest inland bodies of water in the state. The University had previously maintained a summer camp for engineering students, giving them experience in surveying under conditions which can not be provided at Ann Arbor. Five years ago it was decided to move their camp to Douglas Lake, and the idea was conceived of locating a biological station at the same place. Some log buildings were already on the ground, which could be used for laboratories, and the engineers had established facilities for board, so that comparatively. little difficulty or expense was encountered in preparing the site. The first session of the station was inaugurated in 1909, and since that time the thoroughness and value of the work have steadily improved. Both students and faculty have come to see the superiority of camp life over the ordinary sort of biological station. The faculty has discovered that the student does, at an average, twenty-five per cent more work than is done at the University in the same time, while the character of the work is such that it could not possibly be duplicated on the University campus. The student has discovered that he not only learns his science thoroughly, but that he also has a vacation, and returns to his regular work in the fall completely recreated. It is small wonder, then, that the same staff returns year after year, and that the average student spends two seasons at the station, while two of them have been there every one of the past four years.

Douglas Lake, on which the station is located, is only seventeen miles south of the Straits of Mackinac, so that the summer cli- 
mate is delightfully cool. The lake is about four miles long by two and a half miles wide, and is surrounded on every side by rolling hills of sand or clay, covered generally with woods, and very sparsely settled. The margin of the lake is a gently sloping gravelly or sandy beach, with a maximum depth of three to eight feet of water. Beyond this shelf there is a sudden decline in the bottom, and in a very short distance the lake becomes forty to fifty feet deep, with a maximum depth of about eighty feet. The water is clear, and the great depth permits the study of the thermocline and other similar lacustrine phenomena. There are several small streams draining into the lake, but this combined volume is less than that of the outlet, indicating that there are also subaquatic springs. The outlet of the lake is through Maple River into Burt Lake. Although the latter is only a mile and a half from Douglas Lake, the river is over twenty miles long and follows a very circuitous course. There is a difference of one hundred feet in the level of the two lakes, and as a result a vast amount of subterranean drainage through the intervening sand ridges. The most remarkable feature of this is Big Springs, where a million gallons of water per day issue from numerous springs and form a trout stream flowing through a deep gorge to Burt Lake, a mile away.

Originally the native forests were composed chiefly of white and Norway pine, but these have long since been cut for lumber, and at present the prevailing forest growth on the cut-over land is oak, maple, birch, and aspen. More recently the hardwood forests have been cut, but there are still numerous tracts of beech, maple, and hemlock in virgin condition. There are also areas of considerable size covered with arbor-vitæ bog, and many small tamarack and sphagnum bogs. With such a variation in habitats, there is developed a luxuriant flora, and over five hundred and fifty species of flowering plants have been collected within walking distance of camp.

The station is located at the southeast end of the lake, six miles east of Pellston, eight miles northwest of Topinabee, and immediately on the state road from Pellston and Petoskey to Cheboygan. It is consequently easily accessible from either of two railroads.

The laboratory equipment consists of two log buildings, a tent laboratory, and an aquarium shelter. One of the log buildings, known as the "log laboratory," is used chiefly for class work. It is provided through the center with a series of shelves for ap- 
paratus, with other shelves and book cases at either end, and with tables under the windows along the walls. On one side are four tables accommodating fourteen students, and at the other a single long table, used by investigators, and providing ample space for three. At the rear of this building is a lean-to, for the storage of collecting apparatus, nets, tools, and other bulky material, and with a photographic dark-room partitioned off in one corner. Near this laboratory is the aquarium shelter, with several aquaria and a large storage tank. The water is supplied by a windmill, with its intake in the lake. At the same place a substantial dock is built out to deep water, for convenience in using the boats and launches.

The other log building is called the "research laboratory." It contains likewise a set of shelves down the middle, and has three tables at each side near the windows. The building is used exclusively by the staff and research assistants. The tent laboratory is fitted in the same way, with central shelves and tables at the sides. These are assigned to advanced students or used for class work as occasion demands.

The University has provided generously for the equipment of the station, so that it now offers facilities for virtually every line of zoölogy and botany which are ordinarily followed at an inland station. Small articles, glassware, and reagents, are purchased directly by the station and stored there during the winter. $\mathrm{Mi}$ croscopes and other expensive articles are taken to the station from the university for each session. As indication of the equipment, some of its features may be mentioned. For transportation and collection, there are a 28-foot launch, a 16-foot launch, and several rowboats. For collecting, the station has a large number of fish nets, in various styles and sizes, plankton apparatus, dip nets, dredges, insect nets, traps, bird blinds, vasculums, and the like. For photography, there is an excellent box camera of the latest model, a reflecting Graflex with Tessar lens, and an apparatus for subaquatic photography. For the measurement of environmental conditions, there are thermometers of various patterns, evaporimeters, psychrometers, thermophones, photometers, rain-gauges, and soil-borers. For the preservation of specimens, there is a large supply of bottles, boxes, paper cartons, jars, presses and drying paper, insect boxes, stretching frames, and the like. For general convenience in conducting the affairs of the camp, a typewriter and a mimeograph have been provided.

Like the University of Michigan, the station is coeducational. 
The women, under charge of the Dean of Women, occupy quarters at one side of the laboratories, and the men at the other. The tenting accommodations are uniform for both students and staff. Each tent is fourteen feet square, with three-foot wall, covered by a fly, and with a raised floor. The tent poles are permanent, insuring greater solidity than is possible with temporary poles. Each tent is fitted with one or two straw-filled bed ticks, covered with mosquito canopies, and is furnished with washstand, table, chairs, stove, lantern, and other utensils. The occupants furnish their own bedding and towels. Meals are taken at the mess tent, where they are prepared by professional cooks.

Classes are conducted in accordance with a regular program. To each class is assigned one or more whole days per week, giving thus the best opportunity for continuous work. Classes begin at seven-thirty, and continue with an intermission for dinner until late in the afternoon. After that the students' time is free. to be used either in recreation or in study as needed.

Instruction is provided in three courses in botany, forest botany, systematic botany, and ecology, and in four courses in zoölogy, invertebrate zoölogy, vertebrate zoölogy, ornithology, and entomology. Besides these regular courses, opportunity is offered advanced or graduate students to carry on investigation in either botany or zoölogy, under personal direction. Over half the students have been in the past wholly or partly engaged in research work. As an additional incentive to research, there are offered by the station each year research assistantships in both botany and zoölogy, which permit the holder to devote his time exclusively to research, without the payment of fees or the performance of any routine duties.

Out in the woods, six miles from town, and over two miles from the nearest house, the students must be provided not merely with work, but also with amusement. The station has apparently solved this necessity satisfactorily and with the proper division of time between the two. There is a regular hour for swimming every afternoon, and in the evening one laboratory is set aside for use as a recreation room. The boats are available for pleasure trips when not needed for scientific purposes, and there are frequent songs, bonfires, and marshmallow roasts along the beach. The regular hours, the abundant exercise, and the outdoor life make the students strong, and keep them healthy and happy.

The staff at the station has always considered that a field naturalist, whether botanist or zoölogist, should have some knowl- 
edge of woodcraft, and be able to take care of himself properly when engaged in field work. So the students are encouraged to become skilful in setting up tents, in camp cooking, and in other similar features of camp life. These things of course are not compulsory. A camping trip, directed by an experienced woodsman, is sent out every Saturday, and every student is given a chance to go on one of them. Once each season, also, a four-day trip is taken around the neighboring shores of Lake Michigan and Lake Huron. Eight men make the trip, carrying all their supplies on their backs.

After four years experience, the value of the station is assured. The scientific opportunity is unquestioned; the opportunity for renewed physical health and vigor is undoubted. But probably more important than either of these, although less understood or appreciated by the student, is the chance given by eight weeks in the woods to get acquainted with one's self, and to view some of the affairs of life free from the bias of urban conventions.

\section{TURPENTINE.}

Turpentine from western yellow pine, says the Department of Agriculture, can be put to the same uses as that from the longleaf pine of the southeast, which furnishes the bulk of the turpentine of commerce. Western yellow pine forms enormous forests in the Rocky Mountain and Pacific Coast States, while the supply of longleaf is fast melting away. A product very similar to turpentine can be obtained also from pinon pine, another tree common in the southwest.

Careful tests made by the Department have shown that the yield of turpentine and rosin per scason from western yellow pine in Arizona is only two-thirds that from the southeastern pine, the difference being due to fact that the season of flow in the west is about twenty-five weeks, and in the south about thirty-three weeks. During the Civil War, when turpentine operations in the south had virtually ceased, some operations were carried on in California to meet local needs. But with the return of the southern product to the California market, the western operations were abandoned.

The results of a chemical examination of the oils of western yellow, pinon, digger, sugar, and lodgepole pines which have just been published by the Forest Service in an official bulletin show the possibilities of the rosin and turpentine from western yellow and pinon pines as a supplement to the present supplies. Economic problems of markets, transportation, and labor remain to be solved. Information as to how the Forest Service secured the yields upon which the analyses were based is given in another bulletin on the possibilities of western pines as a source of naval stores. 